\title{
BĖGIMO GREIČIO IR LAIPIOJIMO SUKELTO NUOVARGIO POVEIKIS AEROBININKIŲ KOJŲ RAUMENŲ EMG RODIKLIAMS
}

\author{
Kristina Zaičenkoviene ${ }^{1}$, Arvydas Stasiulis ${ }^{1}$, Darius Paknys ${ }^{1}$, Laura Daniusevičiūté ${ }^{2}$, \\ Irina Ramanauskien $\dot{e}^{2}$, Roma Aleksandravičiené $\dot{e}^{1,3}$ \\ Lietuvos kūno kultūros akademija ${ }^{1}$, Kauno technologijos universitetas ${ }^{2}$, \\ Lietuvos žemès ükio universitetas ${ }^{3,}$ Kaunas, Lietuva
}

\begin{abstract}
Kristina Zaičenkovienė. Biologijos mokslų magistrè. Lietuvos kūno kultūros akademijos biomedicinos mokslu krypties doktorantė, Kūno kultūros ir gimnastikos katedros lektorè. Mokslinių tyrimų kryptis — aerobinio ir anaerobinio pajègumo, bioenergetikos greitoji ir lètoji adaptacija.
\end{abstract}

\section{SANTRAUKA}

Tyrimo tikslas — nustatyti bègimo greičio ir laipiojimo sukelto nuovargio poveikị koju raumenu elektriniam aktyvumui didinamo krūvio metu.

Tiriamosios - Lietuvos kūno kultūros akademijos aerobikos specializantès $(n=5)$, kuriu amžius 22,8 4 4,6 m., kūno mase 55,1 5,1 kg, ügis 1,64 00,03 cm. Tiriamosios tris kartus atliko nuosekliai didinama krüvi bègtakiu (NDK) (LE 200 CE, HP Cosmos) - kontrolini, praèjus vienai ir 24 valandoms po intervalinio 24 minučiu laipiojimo prieškrūvio $(L P)$. Tris pirmas minutes begimo greitis sieke $7 \mathrm{~km} / \mathrm{h}$, nuo ketvirtos begimo minutès greitis buvo didinamas kas šešias sekundes po $0,1 \mathrm{~km} / \mathrm{h}$. Krūvis buvo nutraukiamas tada, kai tiriamoji dèl nuovargio nebegalédavo tęsti bègimo reikiamu greičiu. NDK metu buvo registruojama dešinès kojos šlaunies šoninio ir vidinio plačiojo, blauzdos dvilypio raumens vidinès ir šoninès galvos EMG (Biometrics Ltd, UK). EMG buvo analizuojamos naudojant „Biometrics“ programini paketq. Buvo skaičiuojama kiekvieno bègimo žingsnio EMG amplitudès vidutinè kvadratinè vertè (A), integruotas elektrinis raumenu aktyvumas (iEMG) ir EMG galios spektro vidutinis dažnis (VD). Visu NDK metu buvo matuojamas tiriamuju širdies susitraukimu dažnis pulso matuokliu „Polar S810i“ (Suomija). Kiekvienos NDK minutès pabaigoje tiriamosios buvo prašomos subjektyviai żvertinti savo pastangas, o praèjus 24 valandoms po LP ¿vertinti jaučiama skausma koju raumenyse balais pagal Borgo (Borg) skales.

Nustatème, kad šlaunies šoninio ir vidinio raumens galvu iEMG ir EMG A vidutiné kvadratiné vertè rodo didejimo tendencija praejjus vienai ir ypač 24 valandoms po LP, nors užfiksuotas tik vienas statistiškai reikšmingas skirtumas. EMG galios spektro VD rodo mažejimo tendencija, nors skirtumai nèra statistiškai reikšmingi. Abieju dvilypio blauzdos raumens galvu EMG A vidutiné kvadratinè verte ir iEMG taip pat šiek tiek padidèjo praèjus vienai ir 24 valandoms po LP (daugiau vidinès galvos) $(p>0,05)$. EMG galios spektro VD praèjus vienai valandai po laipiojimo testo sumažédavo, o po 24 valandu padidèdavo, nors statistiškai reikšmingai skyrèsi tik vidinès galvos minètas rodiklis, kai greitis buvo $10,5 \mathrm{~km} / \mathrm{h}$. Tik EMG A reikšmingai didejo greitejjant bègimui, tuo tarpu iEMG ir EMG galios spektro VD reikšmingai nekito. Tyrimo rezultatai parodè, kad intervalinis 24 minučiu laipiojimo prieškrūvis, sukeliantis vidutiniška vèluojantį raumenu skausma, menkai veikè koju raumenu EMG rodiklius praejjus vienai ir 24 valandoms po krūvio, kai bègimo greitis buvo nuosekliai didinamas.

Raktažodžiai: nuosekliai didinamas krūvis bègtakiu, laipiojimas, EMG, koju raumenys.

\section{IVADAS}

$\mathrm{E}$ kscentriniai fiziniai pratimai gali sukelti vèluojantị raumenu skausma, raumenu skaidulu pažeida ir sumažinti raumenu funkcines galimybes (Skurvydas et al., 2000; Cheung et al., 2003; Yu et al., 2003). Todèl po neiprastos fizinès veiklos, tokios kaip lipimas, bėgimas žemyn laiptais, laipiojimas ant suolelio, gali pasireikšti vèluojantis raumenu skausmas (Clarkson,
Hubal, 2002). Raumenų EMG pokyčiai atliekant fizini krūvị parodo jų nuovargi, raumenų grupių ir motorinių vienetų rekrutavimo pokyčius (Scheuermann et al., 2001). Kojų raumenų EMG pakinta ilgo 90-ies minučių bėgimo metu (Muraki et al., 2007), po blauzdos ir šlaunies selektyvų nuovargi sukeliančių izokinetinių fizinių pratimų (Keliis, Liassou, 2009). Po ekscentriniu fiziniu pratimu, 
sukèlusių žasto dvigalvio raumens pažeidą, pakinta EMG amplitude, motorinių vienetų aktyvumo sinchroniškumas, veikimo potencialų sklidimo greitis izomterinių susitraukimų metu (Dundon et al., 2008; Dartnall et al., 2009; Piitulainen et al., 2009). Atliekant laipiojimo testus (lipant žemyn nuo suolelio) aktyvūs raumenys dirba ekscentriniu režimu (Newham et al.,1986), ir tai gali sukelti blauzdos raumenų pažeidą, vėluojanti skausmą (Scharf-Olson et al., 1996). Neaptikome duomenu apie tokio krūvio poveiki raumenų EMG rodikliams bègant.

Tyrimo tikslas - nustatyti bėgimo greičio ir laipiojimo sukelto nuovargio poveikị kojų raumenu elektriniam aktyvumui didinamo krūvio metu.

\section{TYRIMO METODIKA}

Tiriamosios. Buvo tiriamos Lietuvos kūno kultūros akademijos aerobikos specializantès $(\mathrm{n}=$ 5), kuriu amžius 22,8 ( $\pm 4,6)$ m., kūno masė 55,1 $( \pm 5,1) \mathrm{kg}$, ūgis 1,64 $( \pm 0,03) \mathrm{cm}$, kūno masès indeksas $20,5( \pm 2,7)$. Tyrimo protokolas aptartas ir patvirtintas Kauno regioniniame biomedicininiu tyrimų etikos komitete.

Nuosekliai didinamas krūvis (NDK). NDK buvo atliekamas bègtakiu (LE $200 \mathrm{CE}$, HP Cosmos). Tris pirmas minutes bejgimo greitis buvo $7 \mathrm{~km} / \mathrm{h}$, nuo ketvirtos bègimo minutès greitis didinamas kas 6 sekundes po $0,1 \mathrm{~km} / \mathrm{h}$. Krūvis buvo nutraukiamas tada, kai tiriamoji dèl nuovargio nebegaledavo tęsti bègimo reikiamu greičiu.

Elektromiografija. NDK metu buvo registruojama dešinès kojos šlaunies šoninio ir vidinio plačiojo, blauzdos dvilypio raumens vidinès ir šoninès galvos EMG (Biometrics Ltd, JAV). Tuo tikslu naudoti paviršiniai bipoliariniai elektrodai, kurie buvo uždedami ant raumens vidurinès dalies, prieš tai odą dezinfekavus ir nušvitrinus. Vèliau EMG buvo analizuojamos naudojant Biometrics programini paketą. Buvo skaičiuojama kiekvieno bėgimo žingsnio EMG amplitudès vidutinè kvadratinè vertè (A), integruotas elektrinis raumenu aktyvumas (iEMG) ir EMG galios spektro vidutinis dažnis (VD).

Pulsometrija. Visų tyrimų metu buvo matuojamas ir registruojamas tiriamujų širdies susitraukimų dažnis (ŠSD) pulso matuokliu Polar S810i (Suomija).

Subjektyvus pastangų vertinimas. Viso NDK metu, naudojant Borgo skalę, tiriamosios buvo prašomos kiekvienos bėgimo minutès pabaigoje balais subjektyviai įvertinti savo pastangas $(6-20)$.
Subjektyvus skausmo vertinimas. Praejjus 24 valandoms po laipiojimo testo, tiriamosios pagal Borgo skalę ịvertindavo jaučiamą skausmą koju raumenyse balais $(0-10)$.

Intervalinis $\mathbf{2 4}$ minučių laipiojimo prieškrūvis (LP). Pradžioje tiriamosios atliko pramankštą, po kurios 8 kartus po 3 minutes laipiojo ant $34 \mathrm{~cm}$ aukščio laiptelio. Tarp laipiojimų buvo pasyviai ilsimasi po 3 minutes (seddima ant suolelio). Tiriamosios buvo skatinamos palaikyti vienodą lipimo tempą pagal muzikos ritmą (120 dūžių / min).

Tyrimo organizavimas. Tyrimai buvo atliekami Taikomosios fiziologijos ir kineziterapijos katedros Sporto fiziologijos laboratorijoje. Buvo prašoma, kad testavimo išvakarèse tiriamosios neatliktų sunkaus fizinio krūvio, o testavimo dieną visiškai nesimankštintų. Tiriamosios tris kartus atliko NDK bėgtakiu - kontrolini, praejus vienai ir 24 valandoms po LP. Pirmą testavimo dieną tiriamosios atliko NDK bėgtakiu. Prieš bėgimą prie tiriamujų kojų šlaunies šoninio ir vidinio plačiojo, dvilypio blauzdos vidinès ir šoninès galvos raumenų buvo priklijuojami Biometrics Ltd. elektrodai (prieš tai odą nušveitus švitriniu popieriumi ir nuvalius spiritu). Bėgimo metu kiekvienos minutès pabaigoje tiriamosios subjektyviai ivertindavo savo pastangas. Iškart po bègimo tiriamosios gulèdavo 5 minutes. Penktą ir dvidešimtą minutę po NDK buvo imamas kraujas iš rankos piršto, ir nustatoma kraujo laktato koncentracija. Po keliu dienų buvo kartojamas tyrimas, kurio metu tiriamosios po pramankštos atlikdavo LP testą, po valandos - NDK bègtakiu. Praejjus 24 valandoms po NDK, tiriamosios trečią kartą eidavo į laboratorija, ivertindavo jaučiamą skausmą kojų raumenyse ir kartodavo bègimo testą.

Matematinè statistika. Tyrimo duomenu analizė atlikta naudojant Excel 2002 ir Statsitica for windows 5.0. programas. Vertinant tyrimų duomenis, skaičiuotas aritmetinis vidurkis, standartinis nuokrypis. Skirtumo tarp rodiklių vidurkių reikšmingumas buvo nustatomas taikant neparametrinius Friedman dviejų veiksnių dispersinę analizę ir Vilkoksono testus. Statistiniam reikšmingumui nustatyti buvo pasirinktas patikimumo lygmuo $\mathrm{p}<0,05$.

\section{REZULTATAI}

Tiriamosios jautè vidutinišką blauzdos raumenu skausmą praejjus 24 valandoms po LP $(4,2$ $( \pm 1,5)$ balo). Subjektyviai suvokiamos tiriamujuc pastangos kas vieną NDK minutę rodè sumažèjimo 
Pav. Subjektyvus pastangų vertinimas nuosekliai greitėjančio bėgimo metu skirtingomis testavimo dienomis (pagal Borgo skalę)

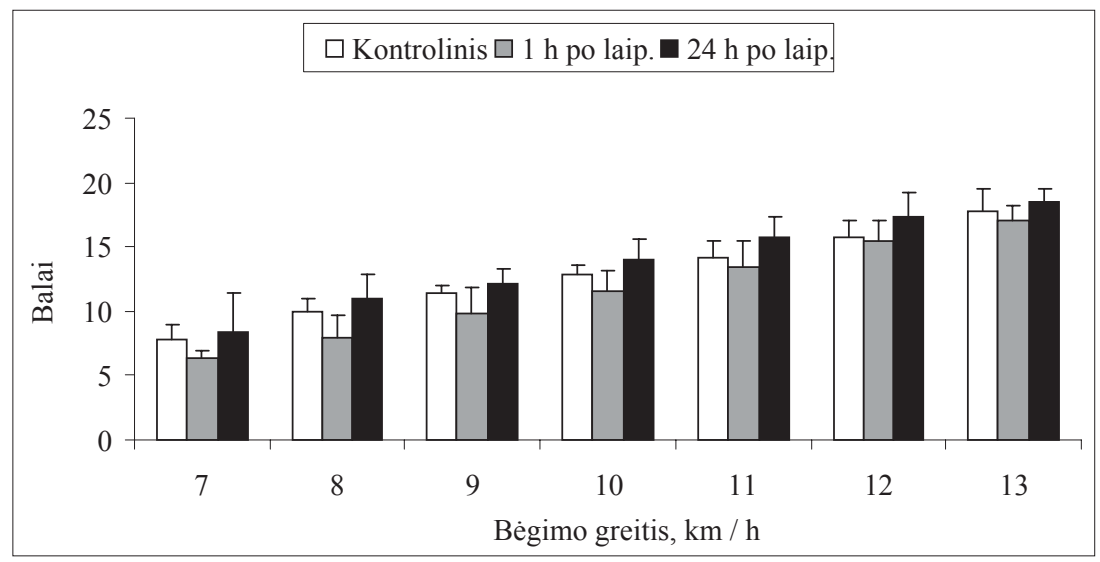

1 lentelè. Aerobininkių šlaunies šoninio plačiojo raumens galvos EMG bėgant skirtingomis testavimo sąlygomis

\begin{tabular}{|c|c|c|c|c|c|c|c|c|c|}
\hline \multirow{3}{*}{$\begin{array}{l}\text { Bègimo } \\
\text { greitis, } \\
\text { km / h }\end{array}$} & \multicolumn{9}{|c|}{ Šlaunies šoninis platusis raumuo (m. vastus lateralis) } \\
\hline & \multicolumn{3}{|c|}{ Amplitudės vidutinė kvadratinė vertė, $\mathbf{m V}$} & \multicolumn{3}{|c|}{$\begin{array}{c}\text { Integruotas elektrinis raumenų } \\
\text { aktyvumas, } \mathrm{mVs}\end{array}$} & \multicolumn{3}{|c|}{$\begin{array}{l}\text { EMG galios spektro vidutinis dažnis, } \\
\qquad \mathrm{Hz}\end{array}$} \\
\hline & Kontrolinis & $1 \mathrm{~h}$ po laip. & 24 h po laip. & Kontrolinis & 1 h po laip. & $\begin{array}{l}24 \text { h po } \\
\text { laip. }\end{array}$ & Kontrolinis & 1 h po laip. & $\begin{array}{l}24 \text { h po } \\
\text { laip. }\end{array}$ \\
\hline 7 & $0,063(0,017)$ & $\begin{array}{c}0,063 \\
(0,008)\end{array}$ & $\begin{array}{c}0,067 \\
(0,014) \\
\end{array}$ & $\begin{array}{c}0,015 \\
(0,003) \\
\end{array}$ & $\begin{array}{c}0,015 \\
(0,002) \\
\end{array}$ & $\begin{array}{c}0,017 \\
(0,002) \\
\end{array}$ & $\begin{array}{c}93,3 \\
(18,4)\end{array}$ & $\begin{array}{c}85,8 \\
(16,6)\end{array}$ & $\begin{array}{c}82,5 \\
(14,2)\end{array}$ \\
\hline 7,5 & $0,069(0,016)$ & $\begin{array}{c}0,070 \\
(0,011) \\
\end{array}$ & $\begin{array}{c}0,071 \\
(0,014)\end{array}$ & $\begin{array}{c}0,015 \\
(0,002) \\
\end{array}$ & $\begin{array}{c}0,016 \\
(0,003) \\
\end{array}$ & $\begin{array}{c}0,017 \\
(0,003)\end{array}$ & $\begin{array}{c}89,7 \\
(20,2)\end{array}$ & $\begin{array}{l}83,97 \\
(17,4)\end{array}$ & $\begin{array}{c}79,9 \\
(10,4)\end{array}$ \\
\hline 8,5 & $0,077(0,020)$ & $\begin{array}{c}0,078 \\
(0,013)\end{array}$ & $\begin{array}{c}0,076 \\
(0,015)\end{array}$ & $\begin{array}{c}0,016 \\
(0,002)\end{array}$ & $\begin{array}{c}0,016 \\
(0,003)\end{array}$ & $\begin{array}{c}0,018 \\
(0,003)\end{array}$ & $\begin{array}{c}83,6 \\
(17,2)\end{array}$ & $\begin{array}{c}82,8 \\
(17,4)\end{array}$ & $\begin{array}{l}76,8 \\
(9,8)\end{array}$ \\
\hline 9,5 & $0,082(0,017)$ & $\begin{array}{c}0,082 \\
(0,013)\end{array}$ & $\begin{array}{c}0,084 \\
(0,016)\end{array}$ & $\begin{array}{c}0,016 \\
(0,002) \\
\end{array}$ & $\begin{array}{c}0,017 \\
(0,003) \\
\end{array}$ & $\begin{array}{c}0,018 \\
(0,003) \\
\end{array}$ & $\begin{array}{c}82,4 \\
(18,9) \\
\end{array}$ & $\begin{array}{c}81,4 \\
(19,1) \\
\end{array}$ & $\begin{array}{c}77,5 \\
(12,7) \\
\end{array}$ \\
\hline 10,5 & $0,084(0,017)$ & $\begin{array}{c}0,084 \\
(0,012)\end{array}$ & $\begin{array}{c}0,088 \\
(0,010)\end{array}$ & $\begin{array}{c}0,016 \\
(0,003)\end{array}$ & $\begin{array}{c}0,017 \\
(0,004)\end{array}$ & $\begin{array}{c}0,018 \\
(0,002)\end{array}$ & $\begin{array}{c}80,6 \\
(18,6)\end{array}$ & $\begin{array}{c}78,6 \\
(20,6)\end{array}$ & $\begin{array}{c}76,6 \\
(14,7)\end{array}$ \\
\hline 11,5 & $0,085(0,015)$ & $\begin{array}{c}0,085 \\
(0,014)\end{array}$ & $\begin{array}{l}0,089 \\
(0,01)\end{array}$ & $\begin{array}{c}0,016 \\
(0,003)\end{array}$ & $\begin{array}{c}0,017 \\
(0,004)\end{array}$ & $\begin{array}{c}0,018 \\
(0,002)\end{array}$ & $\begin{array}{c}79,2 \\
(17,6)\end{array}$ & $\begin{array}{c}75,9 \\
(18,5)\end{array}$ & $\begin{array}{c}73,0 \\
(13,3)\end{array}$ \\
\hline 12,5 & $0,086(0,012)$ & $\begin{array}{c}0,083 \\
(0,016)\end{array}$ & $\begin{array}{c}0,095 \\
(0,015)\end{array}$ & $\begin{array}{c}0,016 \\
(0,004)\end{array}$ & $\begin{array}{c}0,017 \\
(0,004)\end{array}$ & $\begin{array}{c}0,019 \\
(0,001)\end{array}$ & $\begin{array}{l}78,6 \\
(18)\end{array}$ & $\begin{array}{c}74,9 \\
(21,1)\end{array}$ & $\begin{array}{c}69,9 \\
(15,3)\end{array}$ \\
\hline \multicolumn{10}{|c|}{ Statistinis reikšmingumas bėgant skirtingomis testavimo sąlygomis } \\
\hline $\mathrm{p}$ & 0,003 & 0,002 & 0,003 & 0,860 & 0,897 & 0,318 & 0,027 & 0,012 & 0,017 \\
\hline
\end{tabular}

Pastaba. * $-\mathrm{p}<0,05$, patikimas rodiklių skirtumas tarp testavimo dienų.

tendencija praejjus 1 valandai po LP, bet vèl padidẻdavo atliekant NDK po 24 valandų, nors skirtumai nebuvo statistiškai reikšmingi (žr. pav.).

Tirtų raumenu EMG rodiklių vidurkiai atliekant NDK bègtakiu skirtingomis testavimo dienomis pateikti $1-4$ lentelèse. Šlaunies šoninio ir vidinio plačiujų raumens galvų EMG A ir iEMG rodo didejjimo tendenciją praejus vienai ir ypač 24 valandoms po LP, nors užfiksuotas tik vienas statistiškai reikšmingas skirtumas (1, 2 lent.). EMG galios spektro VD rodo mažejimo tendenciją po LP, nors skirtumai nèra statistiškai reikšmingi. Abiejų dvilypio blauzdos raumens galvų EMG A ir iEMG taip pat šiek tiek padidejo praejus vienai ir 24 valandoms po LP (daugiau vidinès galvos) $(p>0,05)(3,4$ lent.). EMG galios spektro VD atliekant NDK 1 valandą po LP sumažėdavo, o po 24 valandų padidèdavo, nors statistiškai reikšmingai skyrèsi tik vidinès galvos minètas rodiklis, kai greitis buvo $10,5 \mathrm{~km} / \mathrm{h}$.

Visų keturių raumenų EMG A reikšmingai didejjo priklausomai nuo bėgimo greičio, tuo tarpu iEMG ir EMG galios spektro VD reikšmingai nekito, nors pastarasis šlaunies šoninio plačiojo raumens galvos rodiklis reikšmingai mažèjo didèjant bėgimo greičiui ( $1-4$ lent.).

\section{REZULTATŲ APTARIMAS}

Šiuo tyrimu nustatème, kad LP, sukeliantis vidutinišką vẻluojantị raumenų skausmą, tik menkai paveikẻ kojų raumenu EMG rodiklius praè- 
2 lentelè. Aerobininkių šlaunies plačiojo vidinio raumens galvos EMG bėgant skirtingomis testavimo sąlygomis

\begin{tabular}{|c|c|c|c|c|c|c|c|c|c|}
\hline \multirow{3}{*}{$\begin{array}{l}\text { Bègimo } \\
\text { greitis, } \\
\text { km / h }\end{array}$} & \multicolumn{9}{|c|}{ Šlaunies vidinis platusis raumuo ( $m$. vastus medialis) } \\
\hline & \multicolumn{3}{|c|}{ Amplitudės vidutinė kvadratinė vertė, $\mathrm{mV}$} & \multicolumn{3}{|c|}{$\begin{array}{c}\text { Integruotas elektrinis raumenų } \\
\text { aktyvumas, mVs }\end{array}$} & \multicolumn{3}{|c|}{$\begin{array}{c}\text { EMG galios spektro vidutinis dažnis, } \\
\mathrm{Hz}\end{array}$} \\
\hline & Kontrolinis & $1 \mathrm{~h}$ po laip. & 24 h po laip. & Kontrolinis & 1 h po laip. & $\begin{array}{l}24 \mathrm{~h} \text { po } \\
\text { laip. }\end{array}$ & Kontrolinis & $1 \mathrm{~h}$ po laip. & $\begin{array}{l}24 \mathrm{~h} \text { po } \\
\text { laip. }\end{array}$ \\
\hline 7 & $0,081(0,026)$ & $\begin{array}{c}0,082 \\
(0,021)\end{array}$ & $\begin{array}{c}0,088 \\
(0,023)\end{array}$ & $\begin{array}{c}0,021 \\
(0,009)\end{array}$ & $\begin{array}{c}0,024 \\
(0,011)\end{array}$ & $\begin{array}{c}0,024 \\
(0,009)\end{array}$ & $\begin{array}{l}73,9 \\
(7,6)\end{array}$ & $\begin{array}{c}72,1 \\
(15,6)\end{array}$ & $\begin{array}{c}63,7 \\
(11,8) \\
\end{array}$ \\
\hline 7,5 & $0,088(0,025)$ & $\begin{array}{c}0,096 \\
(0,020) \\
\end{array}$ & $\begin{array}{c}0,091 \\
(0,028) \\
\end{array}$ & $\begin{array}{c}0,023 \\
(0,009) \\
\end{array}$ & $\begin{array}{c}0,025 \\
(0,011) \\
\end{array}$ & $\begin{array}{c}0,027 \\
(0,005)\end{array}$ & $\begin{array}{l}67,8 \\
(9,0) \\
\end{array}$ & $\begin{array}{c}69,2 \\
(13,5) \\
\end{array}$ & $\begin{array}{c}62,3 \\
(13,9) \\
\end{array}$ \\
\hline 8,5 & $0,098(0,03)$ & $\begin{array}{c}0,103 \\
(0,023)\end{array}$ & $\begin{array}{c}0,109 \\
(0,027)\end{array}$ & $\begin{array}{c}0,021 \\
(0,007)\end{array}$ & $\begin{array}{c}0,024 \\
(0,010)\end{array}$ & $\begin{array}{c}0,026 \\
(0,007)\end{array}$ & $\begin{array}{l}67,3 \\
(7,2) \\
\end{array}$ & $\begin{array}{c}66,9 \\
(12,1)\end{array}$ & $\begin{array}{c}64,2 \\
(12,3)\end{array}$ \\
\hline 9,5 & $0,102(0,035)$ & $\begin{array}{c}0,099 \\
(0,026)\end{array}$ & $\begin{array}{l}* 0,125 \\
(0,037) \\
\end{array}$ & $\begin{array}{c}0,020 \\
(0,008) \\
\end{array}$ & $\begin{array}{c}0,023 \\
(0,008) \\
\end{array}$ & $\begin{array}{c}0,027 \\
(0,007)\end{array}$ & $\begin{array}{l}65,8 \\
(7,8) \\
\end{array}$ & $\begin{array}{l}65,7 \\
(9,6) \\
\end{array}$ & $\begin{array}{c}61,2 \\
(14,8) \\
\end{array}$ \\
\hline 10,5 & $0,106(0,039)$ & $\begin{array}{c}0,108 \\
(0,038)\end{array}$ & $\begin{array}{c}0,126 \\
(0,044)\end{array}$ & $\begin{array}{c}0,02 \\
(0,008)\end{array}$ & $\begin{array}{c}0,022 \\
(0,008)\end{array}$ & $\begin{array}{c}0,026 \\
(0,007)\end{array}$ & $\begin{array}{c}65,3 \\
(10,1)\end{array}$ & $\begin{array}{c}63,8 \\
(10,5)\end{array}$ & $\begin{array}{c}62,7 \\
(10,8)\end{array}$ \\
\hline 11,5 & $0,108(0,034)$ & $\begin{array}{c}0,111 \\
(0,035)\end{array}$ & $\begin{array}{c}0,126 \\
(0,047) \\
\end{array}$ & $\begin{array}{c}0,02 \\
(0,007)\end{array}$ & $\begin{array}{c}0,024 \\
(0,009) \\
\end{array}$ & $\begin{array}{c}0,026 \\
(0,008)\end{array}$ & $\begin{array}{l}71,1 \\
(5,7) \\
\end{array}$ & $\begin{array}{c}63,4 \\
(14,4) \\
\end{array}$ & $\begin{array}{c}63,1 \\
(10,3) \\
\end{array}$ \\
\hline 12,5 & $0,114(0,032)$ & $\begin{array}{c}0,113 \\
(0,044)\end{array}$ & $\begin{array}{c}0,133 \\
(0,058)\end{array}$ & $\begin{array}{c}0,02 \\
(0,007)\end{array}$ & $\begin{array}{c}0,023 \\
(0,009)\end{array}$ & $\begin{array}{c}0,024 \\
(0,009)\end{array}$ & $\begin{array}{c}67,3 \\
(10,2) \\
\end{array}$ & $\begin{array}{c}63,3 \\
(13,9) \\
\end{array}$ & $\begin{array}{l}63,3 \\
(7,7)\end{array}$ \\
\hline \multicolumn{10}{|c|}{ Statistinis reikšmingumas bėgant skirtingomis testavimo sąlygomis } \\
\hline $\mathrm{p}$ & 0,022 & 0,447 & 0,018 & 0,474 & 0,933 & 0,822 & 0,304 & 0,472 & 0,573 \\
\hline
\end{tabular}

Pastaba. $*-p<0,05$, patikimas rodiklių skirtumas tarp testavimo dienų.

3 lentelè. Aerobininkių dvilypio blauzdos raumens šoninės galvos EMG bėgant skirtingomis testavimo sąlygomis

\begin{tabular}{|c|c|c|c|c|c|c|c|c|c|}
\hline \multirow{3}{*}{$\begin{array}{l}\text { Bègimo } \\
\text { greitis, } \\
\mathrm{km} / \mathrm{h}\end{array}$} & \multicolumn{9}{|c|}{ Dvilypio blauzdos raumens šoninė galva (m. gastrocnemius lateralis) } \\
\hline & \multicolumn{3}{|c|}{ Amplitudès vidutinė kvadratinė vertė, $\mathrm{mV}$} & \multicolumn{3}{|c|}{$\begin{array}{c}\text { Integruotas elektrinis raumenụ } \\
\text { aktyvumas, } \mathrm{mVs}\end{array}$} & \multicolumn{3}{|c|}{$\begin{array}{c}\text { EMG galios spektro vidutinis dažnis, } \\
\mathrm{Hz}\end{array}$} \\
\hline & Kontrolinis & $1 \mathrm{~h}$ po laip. & 24 h po laip. & Kontrolinis & $1 \mathrm{~h}$ po laip. & $\begin{array}{l}24 \text { h po } \\
\text { laip. }\end{array}$ & Kontrolinis & $1 \mathrm{~h}$ po laip. & $\begin{array}{l}24 \text { h po } \\
\text { laip. }\end{array}$ \\
\hline 7 & $0,089(0,035)$ & $\begin{array}{c}0,098 \\
(0,039)\end{array}$ & $\begin{array}{c}0,099 \\
(0,027)\end{array}$ & $\begin{array}{c}0,023 \\
(0,008)\end{array}$ & $\begin{array}{c}0,025 \\
(0,038)\end{array}$ & $\begin{array}{c}0,025 \\
(0,008)\end{array}$ & $\begin{array}{c}94,9 \\
(13,5)\end{array}$ & $\begin{array}{c}85,4 \\
(20,2)\end{array}$ & $\begin{array}{c}96,9 \\
(13,6)\end{array}$ \\
\hline 7,5 & $0,096(0,038)$ & $\begin{array}{c}0,105 \\
(0,039)\end{array}$ & $\begin{array}{c}0,107 \\
(0,035)\end{array}$ & $\begin{array}{c}0,023 \\
(0,008)\end{array}$ & $\begin{array}{c}0,025 \\
(0,046)\end{array}$ & $\begin{array}{c}0,024 \\
(0,008)\end{array}$ & $\begin{array}{c}91,6 \\
(14,9)\end{array}$ & $\begin{array}{l}85,2 \\
(22)\end{array}$ & $\begin{array}{c}96,6 \\
(14,2)\end{array}$ \\
\hline 8,5 & $0,102(0,037)$ & $\begin{array}{l}0,110 \\
(0,04)\end{array}$ & $\begin{array}{c}0,105 \\
(0,026)\end{array}$ & $\begin{array}{c}0,023 \\
(0,007)\end{array}$ & $\begin{array}{l}0,025 \\
(0,04)\end{array}$ & $\begin{array}{c}0,023 \\
(0,008)\end{array}$ & $\begin{array}{c}91,0 \\
(14,7)\end{array}$ & $\begin{array}{c}85,9 \\
(20,9)\end{array}$ & $\begin{array}{c}96,9 \\
(14,9)\end{array}$ \\
\hline 9,5 & $0,106(0,029)$ & $\begin{array}{c}0,109 \\
(0,041)\end{array}$ & $\begin{array}{c}0,109 \\
(0,031)\end{array}$ & $\begin{array}{c}0,022 \\
(0,007)\end{array}$ & $\begin{array}{c}0,026 \\
(0,046)\end{array}$ & $\begin{array}{c}0,024 \\
(0,007)\end{array}$ & $\begin{array}{c}89,4 \\
(13,9)\end{array}$ & $\begin{array}{c}83,5 \\
(18,2)\end{array}$ & $\begin{array}{c}97,4 \\
(13,5)\end{array}$ \\
\hline 10,5 & $0,110(0,029)$ & $\begin{array}{c}0,119 \\
(0,045)\end{array}$ & $\begin{array}{c}0,113 \\
(0,031)\end{array}$ & $\begin{array}{c}0,023 \\
(0,006)\end{array}$ & $\begin{array}{l}0,027 \\
(0,05)\end{array}$ & $\begin{array}{c}0,024 \\
(0,006)\end{array}$ & $\begin{array}{c}89,3 \\
(14,1)\end{array}$ & $\begin{array}{c}81,3 \\
(17,6)\end{array}$ & $\begin{array}{l}* 97,0 \\
(11,5)\end{array}$ \\
\hline 11,5 & $0,114(0,027)$ & $\begin{array}{c}0,119 \\
(0,044) \\
\end{array}$ & $\begin{array}{l}0,114 \\
(0,03)\end{array}$ & $\begin{array}{c}0,023 \\
(0,006) \\
\end{array}$ & $\begin{array}{c}0,026 \\
(0,052)\end{array}$ & $\begin{array}{c}0,024 \\
(0,007)\end{array}$ & $\begin{array}{c}90,8 \\
(16,4)\end{array}$ & $\begin{array}{c}80,5 \\
(17,5)\end{array}$ & $\begin{array}{c}97,7 \\
(12,2)\end{array}$ \\
\hline 12,5 & $0,118(0,028)$ & $\begin{array}{c}0,125 \\
(0,046)\end{array}$ & $\begin{array}{c}0,121 \\
(0,034)\end{array}$ & $\begin{array}{c}0,023 \\
(0,006)\end{array}$ & $\begin{array}{c}0,025 \\
(0,052)\end{array}$ & $\begin{array}{c}0,024 \\
(0,005)\end{array}$ & $\begin{array}{c}89,9 \\
(14,0)\end{array}$ & $\begin{array}{c}80,9 \\
(18,0)\end{array}$ & $\begin{array}{c}98,1 \\
(12,9)\end{array}$ \\
\hline \multicolumn{10}{|c|}{ Statistinis reikšmingumas bègant skirtingomis testavimo sąlygomis } \\
\hline $\mathrm{p}$ & 0,006 & 0,005 & 0,011 & 0,504 & 0,719 & 0,411 & 0,514 & 0,870 & 0,447 \\
\hline
\end{tabular}

Pastaba. * - p $<0,05$, patikimas rodiklių skirtumas tarp testavimo dienų.

jus vienai ir 24 valandoms po tokio krūvio, nors pastebèta EMG A ir iEMG padidejimo, o EMG galios spektro VD sumažejjimo (po 1 h), o kitą dieną — padidejjimo tendencija. Iš tirtų rodiklių tik EMG amplitudè reikšmingai didèjo didejjant bègimo greičiui, kiti rodikliai nekito.

EMG tyrimai naudojant paviršinius elektrodus dinaminių judesių metu yra daug retesni (Bi- 
4 lentelè. Aerobininkių dvilypio blauzdos raumens vidinės galvos EMG bėgant skirtingomis testavimo sąlygomis

\begin{tabular}{|c|c|c|c|c|c|c|c|c|c|}
\hline \multirow{3}{*}{$\begin{array}{l}\text { Bègimo } \\
\text { greitis, } \\
(\mathbf{k m} / \mathrm{h})\end{array}$} & \multicolumn{9}{|c|}{ Dvilypio blauzdos raumens vidinė galva (m. gastrocnemius medialis) } \\
\hline & \multicolumn{3}{|c|}{ Amplitudès vidutinė kvadratinė vertė, $\mathbf{m V}$} & \multicolumn{3}{|c|}{$\begin{array}{c}\text { Integruotas elektrinis raumenų } \\
\text { aktyvumas, } \mathrm{mVs}\end{array}$} & \multicolumn{3}{|c|}{$\begin{array}{c}\text { EMG galios spektro vidutinis dažnis, } \\
\mathrm{Hz}\end{array}$} \\
\hline & Kontrolinis & 1 h po laip. & 24 h po laip. & Kontrolinis & 1 h po laip. & 24 h po laip. & Kontrolinis & 1 h po laip. & $\begin{array}{l}24 \text { h po } \\
\text { laip. }\end{array}$ \\
\hline 7 & $0,133(0,037)$ & $\begin{array}{c}0,120 \\
(0,031)\end{array}$ & $\begin{array}{c}0,154 \\
(0,062)\end{array}$ & $\begin{array}{c}0,033 \\
(0,007)\end{array}$ & $\begin{array}{c}0,033 \\
(0,009)\end{array}$ & $\begin{array}{c}0,038 \\
(0,009)\end{array}$ & $\begin{array}{c}118 \\
(13,9)\end{array}$ & $\begin{array}{l}114,2 \\
(15,1)\end{array}$ & $\begin{array}{r}115,3 \\
(13,6)\end{array}$ \\
\hline 7,5 & $0,139(0,036)$ & $\begin{array}{c}0,146 \\
(0,047)\end{array}$ & $\begin{array}{c}0,163 \\
(0,065)\end{array}$ & $\begin{array}{c}0,032 \\
(0,005)\end{array}$ & $\begin{array}{c}0,032 \\
(0,008)\end{array}$ & $\begin{array}{c}0,038 \\
(0,009)\end{array}$ & $\begin{array}{l}116,8 \\
(13,1)\end{array}$ & $\begin{array}{r}114,6 \\
(19,2)\end{array}$ & $\begin{array}{c}114 \\
(14,2)\end{array}$ \\
\hline 8,5 & $0,147(0,034)$ & $\begin{array}{c}0,153 \\
(0,054)\end{array}$ & $\begin{array}{c}0,165 \\
(0,059)\end{array}$ & $\begin{array}{c}0,032 \\
(0,004)\end{array}$ & $\begin{array}{c}0,034 \\
(0,011)\end{array}$ & $\begin{array}{c}0,037 \\
(0,009)\end{array}$ & $\begin{array}{l}116,8 \\
(12,6)\end{array}$ & $\begin{array}{l}108,2 \\
(25,9)\end{array}$ & $\begin{array}{l}112,2 \\
(14,9)\end{array}$ \\
\hline 9,5 & $0,155(0,036)$ & $\begin{array}{c}0,169 \\
(0,074)\end{array}$ & $\begin{array}{c}0,171 \\
(0,052)\end{array}$ & $\begin{array}{c}0,033 \\
(0,004)\end{array}$ & $\begin{array}{c}0,034 \\
(0,009)\end{array}$ & $\begin{array}{c}0,036 \\
(0,009)\end{array}$ & $\begin{array}{l}117,6 \\
(14,1)\end{array}$ & $\begin{array}{l}116,3 \\
(15,5)\end{array}$ & $\begin{array}{l}113,3 \\
(13,5)\end{array}$ \\
\hline 10,5 & $0,160(0,036)$ & $\begin{array}{c}0,176 \\
(0,072)\end{array}$ & $\begin{array}{c}0,179 \\
(0,055)\end{array}$ & $\begin{array}{c}0,032 \\
(0,004)\end{array}$ & $\begin{array}{c}0,036 \\
(0,010)\end{array}$ & $\begin{array}{c}0,037 \\
(0,008)\end{array}$ & $\begin{array}{c}116,9 \\
(14,4)\end{array}$ & $\begin{array}{c}100,9 \\
(22,4)\end{array}$ & $\begin{array}{r}110,2 \\
(11,5)\end{array}$ \\
\hline 11,5 & $0,162(0,039)$ & $\begin{array}{c}0,176 \\
(0,074)\end{array}$ & $\begin{array}{c}0,182 \\
(0,052)\end{array}$ & $\begin{array}{c}0,033 \\
(0,004)\end{array}$ & $\begin{array}{c}0,034 \\
(0,007)\end{array}$ & $\begin{array}{c}0,037 \\
(0,009)\end{array}$ & $\begin{array}{l}116,9 \\
(14,4)\end{array}$ & $\begin{array}{l}104,3 \\
(16,1)\end{array}$ & $\begin{array}{c}111,1 \\
(12,2)\end{array}$ \\
\hline 12,5 & $0,167(0,038)$ & $\begin{array}{c}0,183 \\
(0,063)\end{array}$ & $\begin{array}{c}0,192 \\
(0,056)\end{array}$ & $\begin{array}{c}0,034 \\
(0,004)\end{array}$ & $\begin{array}{c}0,033 \\
(0,006)\end{array}$ & $\begin{array}{c}0,036 \\
(0,008)\end{array}$ & $\begin{array}{l}115,9 \\
(13,6)\end{array}$ & $\begin{array}{l}105,1 \\
(14,1)\end{array}$ & $\begin{array}{l}110,6 \\
(12,9)\end{array}$ \\
\hline \multicolumn{10}{|c|}{ Statistinis reikšmingumas bėgant skirtingomis testavimo sąlygomis } \\
\hline $\mathrm{p}$ & 0,0002 & 0,001 & 0,002 & 0,730 & 0,423 & 0,451 & 0,808 & 0,381 & 0,055 \\
\hline
\end{tabular}

Pastaba. * $-\mathrm{p}<0,05$, patikimas rodiklių skirtumas tarp testavimo dienų.

gland-Ritchie and Woods, 1974; Gamet et al., 1993), negu izometrinèmis raumenų susitraukimo sąlygomis (Enoka, Stuart, 1992). Tiek atliekant nuosekliai didinamą (Bigland-Ritchie, Woods, 1974), tiek pastovaus intensyvumo krūvị (Arnaud et al., 1997) iEMG ar EMG A didejja proporcingai krūviui.

Kojų tiesiamujų raumenu EMG amplitudè atramos fazèje didèja kaip ir bėgimo greitis (Mero, Komi, 1987), o dauguma raumenu EMG A priklauso nuo intensyvumo atliekant nuolat didinamą krūvi veloergometru (Hug et al., 2006). Tai iš esmès sutampa su mūsų gautaisiais duomenimis. Kiti tyrèjai pastebejo iEMG priklausomybę nuo bėgimo greičio, nors jų tyrimo protokolas buvo kitoks (Hanon et al., 1998). Tai paaiškina skirtingus mūsų tyrimo duomenis, kadangi nebuvo užfiksuota reikšmingo iEMG didejjimo didejant bėgimo greičiui. Mes taikème nuolat didinamo krūvio protokolą, o minèti autoriai bègimo greiti didindavo pakopomis kas 4 minutes.

EMG pokyčių nuovargio metu duomenys yra prieštaringi, o duomenų interpretavimas sudètingas (Dimitrova, Dimitrov, 2003). Nesutampa ir atskiru tyreju gauti duomenys, kaip nuovargis veikia raumenų EMG dinaminio krūvio metu. Bègant 30 minučių dideliu intensyvumu, blauzdos dvilypio raumens iEMG nepakito, EMG galios spektro VD padidèjo (Mizrahi et al., 2000). Po izokinetinio blauzdos ar čiurnos raumenų prieškrūvio padidejo blauzdos dvilypio raumens ir šlaunies vidinio plačiojo raumens EMG A (Kellis, Liassou, 2009), o nuvargusių blauzdos raumenų elektrinis aktyvumas bėgant sumažèjo (Weist et al., 2004). Mūsų duomenys nerodo reikšmingo LP sukelto nuovargio poveikio EMG rodikliams, nors matomos tokio poveikio tendencijos. Tai gali būti susiję su nedidele tyrimo statistine galia (apie 20\%) dèl mažo tiriamuju skaičiaus ir dideliu EMG rodiklių standartinių nuokrypių. Ko gero, tokius rezultatus galejjo lemti ir tirtų aerobininkių raumenų adaptacija prie panašių kaip laipiojimas fizinių krūvių, per mažas LP intensyvumas. Kadangi kitą dieną po laipiojimo tiriamosios jautè tik vidutini blauzdu skausmą. Taikant didesni prieškrūvio intensyvumą, reikètų ištirti daugiau tiriamujų.

Ekscentriniai fiziniai pratimai sukelia vèluojantị raumenų skausmą, ilgalaiki jẻgos sumažèjimą, raumenu kontraktūras ir raumenu fermentu koncentracijos kraujyje padidejjimą (Ebbeling, Clarkson, 1989). Tai galètų padidinti nuvargusių raumenu elektrini aktyvumą bėgimo metu. Po klasikinių R. G. Edwards ir D. C. J. Lippold (1956) tyrimų daugelis tyrejų EMG A ir iEMG padidejimą nuovargio metu aiškina kaip papildomu motorinių vienetų rekrutavimo, siekiant kompensuoti dirbančiu skaidulu jègos sumažèjimą, pasekmę (Jørgensen et al., 1988; Gandevia, 2001). Taip pat 
EMG amplitudès padidejimas siejamas su motorinių vienetų impulsavimo dažnumo ar impulsavimo sinchroniškumo pokyčiais (Maton, Garmet, 1989; Linssen et al., 1993).

Nors izometrinių susitraukimų metu dauguma autoriu aptinka EMG galios spektro vidurinio ar vidutinio dažnio sumažèjimą (Loscher et al., 1994), kai kurie abejoja EMG spektrinès analizès informatyvumu atliekant dinaminius susitraukimus (Knaflitz, Bonato, 1999). EMG spektras dinaminiu judesių metu gali priklausyti nuo judesiu apmplitudès pokyčių (MacIsaac et al., 2000). Yra duomenu, kad motorinių vienetų veikimo potencialų sklidimo greitis sumažejja po raumenų pažeidos (Heda- yatpour et al., 2009), ir tai galètu paveikti EMG galios spektro charakteristikas. Mūsų tyrimo metu nebuvo reikšmingu EMG galios spektro pokyčių, nors nevienareikšmès kitimo tendencijos, lyginant atskirus raumenis ir testavimo dienas, gali būti susiję su anksčiau minètomis priežastimis.

\section{IŠVADA}

Intervalinis 24 minučiu laipiojimo prieškrūvis, sukeliantis vidutinišką vèluojantị raumenų skausmą, nedaug paveikia kojų raumenu EMG rodiklius praejus vienai ir 24 valandoms po nuosekliai didinamo bėgimo krūvio.

\section{LITERATŪRA}

Bigland-Ritchie, B., Woods, J. J. (1974). Integrated EMG and oxygen uptake during dynamic contractions of human muscles. European Journal of Applied Physiology, 36 (4), $475-479$.

Cheung, K., Hume, P., Maxwell, L. (2003). Delayed onset muscle soreness: treatment strategies and performance factors. Sports Medicine, 33 (2), 145-164.

Clarkson, P. M., Hubal, M. J. (2002). Exercise-induced muscle damage in humans. American Journal of Physical Medicine \& Rehabilitation / Association of Academic Physiatrists, 81 (11), S 52-69.

Dartnall, T. J., Rogasch, N. C., Nordstrom, M. A., Semmler, J. G. (2009). Eccenric muscle damage has variable effects on motor unit recruitment thresholds and discharge patterns in elbow flexor muscles. Journal of Neurophysiology, 102 (1), 413-23.

Dimitrova, N. A., Dimitrov, G. V. (2003). Interpretation of EMG changes with fatique: Facts, pitfalls, and fallacies. Journal of Electromiography and Kynesiology, 13, $13-36$

Dundon, J. M., Cirillo, J., Semmler, J. G. (2008). Low frequency fatigue and neuromuscular performance after exercise - induced damage to elbow flexor muscles. Journal of Applied Physiology, 105 (4), 1146-1155.

Ebbeling, C. B., Clarkson, P. M. (1989). Exercise-induced muscle damage and adaptation. Sports Medicine, 7(4), 207-234.

Edwards, R. G., Lippold, O. C. J. (1956). Relation between force and integrated electrical activity in fatigued muscle. The Journal of Physiology (Lond.), 132, 677-681.

Enoka, R. M., Stuart, D. G. (1992). Neurobiology of muscle fatigue. European Journal of Applied Physiology, 72 (5), 1631-1648.

Gamet, D., Duchene, J., Garapon-Bar, C., Goubel, F. (1993). Surface electromyogram power spectrum in human quadriceps muscle during incremental exercise. European Journal of Applied Physiology, 74 (6), 2704-2710.

Gandevia, S. C. (2001). Spinal and supraspinal factors in human muscle fatigue. Physiological Reviews, 81, $1725-1789$.

Hanon, C., Thepaut-Mathieu, C., Hausswirth, C., LeChevalier, J. M. (1998). Electromyogram as an indicator of neuromuscular fatigue during incremental exercise. European Journal of Applied Physiology, 78 (4), 315-323.
Hedayatpour, N., Falla, D., Arendt-Nielsen, L., VilaCha, C., Farina, D. (2009). Motor unit conduction velocity during sustained contraction after eccentric exercise. Medicine and Science in Sports and Exercise [Epub ahead of print].

Hug, F., Laplaud, D., Lucia, A., Grelot, L. (2006). A comparison of visual and mathematical detection of the electromyographic threshold during incremental pedaling exercise: A pilot study. Journal of Strength and Conditioning Research, 20 (3), 704-708.

Jørgensen, K., Fallentin, N., Krogh-Lund, C., Jensen, B. (1988). Electromyography and fatigue during prolonged, low-level static contractions. European Journal of Applied Physiology, 57, 316-321.

Kellis, E., Liassou, C. (2009). The effect of selective muscle fatigue on sagittal lower limb kinematics and muscle activity during level running. The Journal of Orthopaedic and Sports Physical Therapy, 39 (3), 210220.

Knaflitz, M., Bonato, P. (1999). Time-frequency methods applied to muscle fatigue assessment during dynamic contractions. Journal of Electromyography and Kinesiology, 9 (5), 337-350.

Linssen, W. H. J. P., Stegeman, D. F., Joosten, E. M. G. et al. (1993). Variability and interrelationships of surface EMG parameters during local muscle fatigue. Muscle Nerve, 16, 849-856.

Loscher, W. N., Cresswell, A. G., Thorstensson, A. (1994). Electromyographic responses of the human triceps surae and force tremor during sustained submaximal isometric plantar flexion. Acta Physiologica Scandinavica, 152 (1), $73-82$.

Maclsaac, D., Parker, P. A., Scott, R. N. (2000). Non-stationary myoelectric signals and muscle fatigue. Methods of Information in Medicine, 39 (2), 125-129.

Maton, B., Gamet, D. (1989). The fatigability of two agonistic muscles in human isometric voluntary submaximal contraction: an EMG study. II Motor unit firing rate and recruitment. European Journal of Applied Physiology, $58,369-374$.

Mero, A., Komi, P. V. (1987). Electromyographic activity in sprinting at speeds ranging from sub-maximal to supramaximal. Medicine and Science in Sports and Exercise, 19 (3), 266-274. 
Mizrahi, J., Verbitsky, O., Isakov, E. (2000). Fatigue-related loading imbalance on the shank in running: A possible factor in stress fractures. Annals of Biomedical Engineering, 28 (4), 463-469.

Muraki, S., Yanagawa, K., Fukuoka, Y., Niihata, S. (2007). Changes in EMG characteristics and metabolic energy cost during 90-min prolonged running. Gait \& Posture, 26 (4), 607-610.

Newham, D. J., Jones, D. A., Tolfree, S. E., Edwards, R. H., (1986). Skeletal muscle damage: A study of isotope uptake, enzyme efflux and pain after stepping. European Journal of Applied Physiology, 55 (1), 106-112.

Piitulainen, H., Bottas, R., Komi, P., Linnamo, V., Avela, J. (2009). Impaired action potential conduction at high force levels after eccentric exercise. Journal of Electromyography and Kinesiology [Epub ahead of print].

Scharff-Olson, M., Williford, H. N., Blessing, D. L., Brown, J. A. (1996). The physiological effects of bench / step exercise. Sports Medicine, 164-175.
Scheuermann, B. W., Hoelting, B. D., Noble, M. L., Barstow, T. J. (2001). The slow component of $\mathrm{O}_{2}$ uptake is not accompanied by changes in muscle EMG during repeated bouts of heavy exercise in humans. Journal of Physiology, 15, 531 (Pt 1), 245-256.

Skurvydas, A., Jascaninas, J., Zachovajevas, P. (2000). Changes in height of jump, maximal voluntary contraction force and low-frequency fatigue after 100 intermittent or continuous jumps with maximal intensity. Acta Physiologica Scandinavica, 169 (1), 55-62.

Yu, J. G., Furst, D. O., Thornell, L. E. (2003). The mode of myofibril remodelling in human skeletal muscle affected by DOMS induced by eccentric contractions. Hiostochemistry and Cell Biology, 119 (5), 383-393.

Weist, R., Elis, E., Rosenbaum, D. (2004). The influence of muscle fatigue on electromyogram and plantar pressure patterns as an explanation for the incidence of metatarsal stress fractures. The American Journal of Sports Medicine, 32 (8), 1893-1898.

\title{
THE EFFECT OF RUNNING SPEED AND FATIGUE INDUCED BY PRIOR STEPPING ON EMG OF LEG MUSCLES IN AEROBIC STUDENTS
}

\author{
Kristina Zaičenkoviene ${ }^{1}$, Arvydas Stasiulis ${ }^{1}$, Darius Paknys ${ }^{1}$, Laura Daniusevičiūtè ${ }^{2}$, \\ Irina Ramanauskiene் $\dot{e}^{2}$ Roma Aleksandravičiené $\dot{1}^{1,3}$ \\ Lithuanian Akademy of Physical Education ${ }^{1}$, Technology University of Kaunas ${ }^{2}$, Lithuanian \\ Agricultural University, ${ }^{3,}$ Kaunas, Lithuania
}

\begin{abstract}
The aim of the study was to determine the influence of running speed and fatigue induced by prior step exercise on the electrical activity of leg muscles during increasing exercise. Five aerobic students aged 22.8 \pm 4.6 ) years, body weight $55.1 \pm 5.1 \mathrm{~kg}$ and height $1.64 \pm 0.03)$ of the Lithuanian Academy of Physical Education participated in the study. They performed increasing ramp running test (IRT) on a treadmill (LE $200 \mathrm{CE}, \mathrm{HP}$ Cosmos) under three different conditions (control, one hour and 24 hours after prior exercise (24 min of interval step exercise (height of the Step - $40 \mathrm{~cm}$ )). EMG (Biometrics Ltd, UK) of right leg m. vastus lateralis, $\mathrm{m}$. vastus medialis, lateral and medial heads of $\mathrm{m}$. gastrocnemius were continuously recorded. The subjects were asked to evaluate perceived exertions at the end of each minute of IRT. Day after the eccentric exercise, all subjects reported leg muscle soreness using the Borg's CR-10 scale. Measures of the recruited muscles activity were analyzed using available software (Biometrics Data Log).

The results showed that iEMG and EMG A of $\mathrm{m}$. vastus lateralis and $\mathrm{m}$. vastus medialis tended to increase one and especially $24 \mathrm{~h}$ after PSE ( $p>0.05$ ). The mean frequency of EMG power spectrum demonstrated tendency to decrease $(p>0.05)$. Similarly iEMG and EMG A slightly increased one and $24 \mathrm{~h}$ after PSE for both heads of $\mathrm{m}$. gastrocnemius $(\mathrm{p}>0.05)$. The mean freaquency of EMG power spectrum decreased one hour, but again increased 24 hours after PSE ( $p>0.05$ ). Only EMG amplitude demonstrated significant increase with the increase of running speed with no significant changes of $\mathrm{EEMG}$ and MF of EMG power spectrum.

We conclude that preceding step exercise seems to have only small residual effect (within 1-24 hours of recovery) on leg muscles EMG dynamics during IRT in aerobic students. Only EMG A increases in parallel with running speed.
\end{abstract}

Keywords: increasing treadmill running, stepping, EMG, leg muscles.

Gauta 2010 m. kovo $15 \mathrm{~d}$.

Received on March 15, 2010

Priimta 2010 m. gegužès $31 \mathrm{~d}$

Accepted on May 31, 2010
Kristina Zaičenkovienè

Lietuvos kūno kultūros akademija

(Lithuanian Academy of Physical Education)

Sporto g. 6, LT-44221 Kaunas

Lietuva (Lithuania)

$\mathrm{Tel}+37061620238$

E-mail zaicenkoviene@yahoo.co.uk 